\title{
Panel Discussion: To Build a National Commitment
}

Congress Chairman: C.H. Geale Before introducing your moderator I wish to introducee the panel starting from coast to coast. From Newfoundland, The Honourable Len Simms, Minister of Forest Resources and Lands. From Nova Scotia, The Honourable Ken Streatch, Minister of Lands and Forests. From New Brunswick. The Honourable Malcolm MacLeod, Minister of Foresters, Mines and Energy. From Quebec, The Honourable Albert Côté, Minister of Forests. From Ontario, The Honourable Vincent Kerrio, Minister of Natural Resources. From Saskatchewan, The Honourable Colin Maxwell, Minister of Parks and Renewable Resources. Replacing Don Sparrow the Minister of Forestry for Alberta, is Frank Appleby, Member of the Alberta Legislature and Chairman of the Government Forestry Caucus Committee. From British Columbia, The Honourable Jack Heinrich, Minister of Forests. The wrap-up speaker will be The Honourable Gerald Merrithew, Minister of State for Forestry.

I'd like now to introduce the moderator of this session, Pamela Wallin. Appointed CTV Ottawa Bureau Chief in January 1985, Miss Wallin is the only woman in Canadian television history to hold the position of bureau chief. Prior to this appointment she co-hosted Canada AM, the only live, national, early morning news and information program in the country. Miss Wallin joined CTV in June, 1981 as the Ottawabased host-reporter for Canada AM. Before joining CTV, Pamela was a political reporter for the Ottawa bureau of The Toronto Star and appeared on CTV's Question Period regularly. Welcome and I now turn it over to you, Pamela.

Panel Moderator: Miss Pamela Wallin, Ottawa Bureu Chief, CTV. Ministers, ladies and gentlemen. I'm pleased to be part of this session and sit at this table with so many distinguished guests. I still haven't quite figured out why they invited a native of the Saskatchewan plains to talk about trees, but in fact, it does indicate that there are many people in this country, perhaps inside government and perhaps even inside industry, that do not know yet how serious a challenge we are potentially facing. Everything, Dr. Paillé was saying, from pollution to productivity affects this very crucial industry.

This conference was to be a catalyst for action and this session in particular is about what next? We are here today to try and find ways to ensure a strong commitment to respond to the problems of the forest industry and in forest management. We are here also to secure, if possible, that often elusive political will needed if there is to be action and if there is to be money dedicated to these problems.

As ministers responsible in each of your own jurisdictions, you are aware of the problems. They were highlighted very well by Dr. Paillé's presentation and discussed over the last two days and throughout this session. We'll be asking each of you to respond briefly to questions that will be forthcoming from the audience. In television we have a rule that if it can't be said in a minute-thirty, it's not worth saying so we will see if we can keep that rule today. I do not want to appear rude but I am going to ask you all, Ministers, to please keep your platitudes to a minimum when you are answering these questions. We are dealing with a sophisticated audience, people who understand the issues, and I think they want to get down to specifics. I earn my living, of course, trying to get politicians to say things they don't want to say and I know how frustrating it can be.

This is an issue, as I think everybody is aware, that is both politically sensitive and politically important. In this country in many ways our forests are part of all our identities. As citizens we are pround and protective of that heritage, so the future of our forests is really not just an economic issue, it is also an emotional one. I think that we should try and focus on that range, that being the scope of the debate today. We were going ot hear briefly from each of the Ministers, but they had a better idea and that was to call on the Chairman of the Canadian Council of Forest Ministers, The Honourable Albert Côté, from the province of Québec, to respond on all their behalves to the presentation by Dr. Paillé. After that we will then raise some particular questions. Mr. Côté go ahead.

Panelist: Hon. Albert Côté. Thank you Miss Wallin. First I would like to congratulate the organizers of this National Forest Congress and to thank everyone who has helped arrange and take part in these sessions. They have helped to clarify the nature of Canada's forestry challenge and what must be done to protect, manage and use our forests on the principles of sustained yield and multiple use. I would also like to thank those special people at this Congress - The Right Honourable Brian Mulroney, Chairman Chuck Geale and his team, the Program Chairman Gilbert Paillé, Logistics Chairman Bert Joss, and the Congress Co-ordinator Bill Foster. Finally I would like to thank my friends and colleagues from the governments of Canada, the provinces and the Yukon and Northwest Territories who have shown such great interest in this Congress and in the future of our forests.

As Miss Wallin has mentioned, it is because our forests are important in so many ways to all of us that the Forestry Ministers for the first time organized a series of forums across Canada that helped lay the foundation for this Congress and for the recommendations which Dr. Paillé has presented. Clearly, as Forestry Ministers, we cannot immediately respond and act on these but we do pledge to examine them closely 
and to accept or reject them. We shall do everything possible to meet the forestry challenge in Canada and to get public support for it.

The Canadian Council of Forest Ministers has agreed to launch a national publicity and communications campaign to help make the Canadian people more aware of the importance of forests to their economy, lifestyle and environment. This program will cost $\$ 4$ million over two years and will be cost-shared between the federal and each of the provincial and territorial governments. I invite industry and others in the forest sector to join this public awareness campaign.

Panel Moderator: Pamela Wallin. Thank you Mr. Côté. I think I'll turn very briefly now to The Honourable Gerald Merrithew: he would like to add some comments.

Panelist: Hon. Gerald Merrithew. Thank you very much Pamela. I want to re-emphasize on behalf of the Canadian Council of Forest Ministers what our Chairman has just said. When we formed in September - that's only seven months ago - we had three or four major goals. We were very much aware that the public doesn't understand forestry very well. Some do not appreciate enough the impact it has on the Canadian economy, the number of jobs, importance of trade the number of individual communities affected. We said we'd try to raise the forestry profile and the public awareness of it in response to recommendations out of every one of the four forestry forums we held across Canada. We somehow must find a way to tell our story better. Our Forestry Ministers agreed that we would jointly fund a \$4-million public awareness campaign over a two-year period in television and print media and that we would try to tell the Canadian people how important the forest sector is to them. I want to thank our chairman and all my colleagues for working together to make this happen so quickly.

Panel Moderator: Pamela Wallin. I think that has been one of the issues that has been raised repeatedly over the last two days. We don't know as much as we should and I think everyone would applaud spending money to make this issue more visible and more presentable.

Getting now to some of the questions from the audience, the first question l've got here is that they want commitments for money, not just for raising awareness of this issue but commiting long-term funding to forest management to provide jobs. We'll start with you Mr. Merrithew. Is it possible that the kind of federal/provincial agreements that you are into, the five-year plans, are not good enough, that if you're going to solve this problem you must have a longer-range approach?

Panelist: Hon. Gerald Merrithew. There's no question on that, Pam. The industry has asked us repeatedly for some sort of long-term assurance that assistance will be there to the sector. I concur with that. We have put our money where our mouth is in terms of agreements with the provinces. We have gone from $\$ 225$ million to almost $\$ 1.1$ billion, that's a $400 \%$ increase in one year. I think that's pretty good but they do need a longer-term commitment and only governments can give that, but a government's term is not very long sometimes.

Panel Moderator: Pamela Wallin. Maybe we could hear from Mr. Heinrich from British Columbia, a new minister just into the portfolio, and how he sees it as he comes in with a fresh eye and whether or not his assessment of the funding arrangements is an adequate approach.

Panelist: Hon. Jack Heinrich Madame Moderator, I think it was an excellent beginning. I'm now seven weeks into the portfolio and had a wonderful opportunity for the last two and a half days to hear about a number of issues. As far as British Columbia is concerned, it's a joint program worth $\$ 300$ million over five years, but I don't think that is going to be adequate and it's abundantly clear from all of those in the forest sector within British Columbia that it's not. We've introduced a bill in the House two weeks ago, trying to raise another $\$ 70$ million. It would be superb if we could get an expenditure in B.C. for reforestation up to $\$ 300$ million. I don't think we'll reach that for a while but that is our objective and the provinical/federal agreement has been a great start.

Panel Moderator: Pamela Wallin. Now to the other end of the country. May we have some comments on the question from Nova Scotia, from Mr. Streatch.

Panelist: Hon. Kenneth Streatch. Madame Moderator, I think that we've identified forestry in Nova Scotia as being one of our major priorities for economic development and longterm permanent jobs and, as such, we've also indicated that it is a shared responsibility as far as funding that resource. As we've heard here over the last couple of days, it's a type of resource that you don't plant today and harvest tomorrow. That means long-term commitments on behalf of governments. Certainly, speaking on behalf of the government of Nova Scotia, we've made that commitment in establishing a new forest policy for Nova Scotia. I would also give credit where credit is due, to the federal government with the appointment of Gerry Merrithew as federal minister and the commitment that he has initiated on behalf of all of us across Canada. It seems to me that conditions are right for long-term commitments on behalf of both provincial and federal governments.

Panel Moderator: Pamela Wallin. Is there anyone else who would like to respond to that?

Panelist: Hon. Vincent Kerrio. Thank you Pamela. I don't think that all of the responsibility has to do with money. Rather than boast individually about what we do in each province, I think that this Council is going to share some of the research and development and other programs that we've put into place. I'm very enthusiastic about what's happened here and we have made a commitment to have an ongoing forum that's going to be sharing those things. Yes, money to a point, but really the kind of determination that's been made by this Council, I think, is just as important.

Panel Moderator: Pamela Wallin. Another question from our audience asks whether industry should not be more directly involved, and perhaps signators to these federal/provincial agreements?

Panelist: Hon. Gerald Merrithew. Anyone who wants to be involved, put their money up. These agreements, remember, are federal/provincial. There are lots of mechanisms by which we consult with the industry. Every minister at this table meets with industry and with woodlot owners and so on, so there is a mechanism by which we consult and they can have their views put forward. I don't know whether provinces would agree to having industry say all the money must go on freehold lands or should be done this way, instead of the way the provinces in their own sovereign way would wish.

Panelist: Hon. Len Simms. One important point that should be made in response to your questions is that there are, in fact, mechanisms already in place in some if not all federal/ 
provincial agreements. I'm not aware of all of them, but they certainly exist in ours and in Nova Scotia's. There are agreements were silviculture programs with the paper companies are cost-shared by the companies, the province and the federal government. In our case, as well, we have funding for cost-shared resource road construction so the question is really not apropos to Newfoundland at least, because there is a funding mechanism there now. Maybe the questions is, should there be more, and anybody who's realistic would say, sure, but where are you going to get it and that's the bottom line in any question.

Panel Moderator: Pamela Wallin. I'm just wondering if there are mechanisms, perhaps, for bringing the industry in that would allow both federal and provincial ministers more direct control. I understand your relationship to the forest, but I wonder what it is over the direct activities and behaviour of industry that you may want to alter in some way.

Panelist: Hon. Len Simms. Well, there's always room for improvement and alterations. We've been trying to alter things in the country and as time goes on you make progress, and in that particular area we've made some progress but I think more could be made, yes.

Panel Moderator: Pamela Wallin. Alberta has a reputation of having a fairly successful forestry management system. Are there some secrets, some tricks there?

Panelist: Mr. Frank Appleby. Thank you Pamela. I don't know if there's any secret to what we have in Alberta, but I would like to say before I say anything else, that our Minister, The Honourable Don Sparrow, is not with us this afternoon because he had to go back to Edmonton to run past his Cabinet colleagues a major statement on forestry which he'll be making in the legislative assembly tomorrow. We in Alberta feel that we have an enlightened relationship with industry which has produced a good forest management program in the province. It was initiated some 30 years ago and developed to allow both public and private sectors to work together effectively on Crown timber allocations.

Panel Moderator: Pamela Wallin. Perhaps we could hear from Saskatchewan as well. Not, as we said earlier, a whole lot of trees but

Panelist: Hon. Colin Maxwell. Well, Pamela I would definitely like to invite you to come back to your native province and I'll personally give you a tour of the 20 million acres of productive forest land we have and the other 96 million acres of resource land that my department also administers. Not to downplay your question, we are small players in the forest industry in Saskatchewan, we recognize that, but not so small as to prevent us from attracting a major industry to our province in the form of Weyerhaeuser who will be coming into Saskatchewan with open arms, and if there are any others out there interested in taking a look at our province give me a call after the meeting.

Panel Moderator: Pamela Wallin. Well, it didn't exactly answer the question but we do know that Saskatchewan is open for business and there is an election coming up. I'd like to put a question now to Mr. Kerrio and I know it's been a troublesome one for you. It's got to do with spraying for insect control. I know that's caused you some problems and the question that's being put to you is how much timber do you think is at risk in Ontario and, in addition to that, what's the trade-off? How do you weigh environmental concerns against the economic concerns of the industry?

Panelist: Hon. Vincent Kerrio. Pamela, I think at the outset you talked about political will. I've been in politics some eleven years now and I've had three out of four minority governments. I want to tell you that when there's more people sitting on the other side than there are on the government benches, a great deal of your political will is taken from you. What I have to say is that we - my foresters - had put a proposal forward and had open houses where we put it to the people of Ontario as to whether that was acceptable or not. We had good support for it in the affected areas. We were talking about a mix of about $94 \%$ biological spray and about $6 \%$ chemical and I want to keep that in perspective because we were not just talking about spraying chemicals. We wanted that consultative process to run its course but that option was taken away. There was some concern about the politics of it and the opposition parties decided that they would not allow a spraying program to go forward unless we eliminated the chemicals and that's precisely what happened. We're going forward, in Ontario, with a \$21-million program that's biological and this was about the circumstance that developed.

Panelist: Hon. Alberte Côté. I hope that my colleague from Ontario will keep his insects in his province because they always travel towards the east. In Quebec I am negotiating with my colleague, the Minister of Environment, to spray next year for insect entirely with Bt. This year we had the same proportion of $\mathrm{Bt}$ to chemicals as was proposed in Ontario, namely $90-95 \% \mathrm{Bt}$ and $5-10 \%$ chemical.

Panel Moderator: Pamela Wallin. We haven't heard from a couple of people yet. We will ask Mr. MacLeod from New Brunswick some general questions being put forward to everybody. Again, the theme seems to be the relationship between the industries and the government and your assessment of that.

Panelist: Hon. Malcolm MacLeod. Our province, I think, took the right approach. We did go to industry, to the small woodlot owners and the large freehold land people, and put together what we consider to be a pretty good forest plan. I think the province of Quebec and the province of Nova Scotia soon followed us and we feel we are somewhat leaders in establishing a forest plan because we had one early. It does call for joint participation and for joint management. In its simple form, a major license goes to the person with the wood requirement who then deals with sub-licensees. It has a cost structure and so on and is really a good model. There are people here in the room today who worked on that model and I take no credit for it, but give it to Gerry Merrithew, my predecessor, and the Minister before him.

Panel Moderator: Pamela Wallin. Several of the questions here also seem to be getting at the issue of consultation, not just with industry but with the public as well, and how do you draw the line on that. If you're always responding to public concerns and public pressures, that's obviously going to present operating problems for industry. The public point of view is that the use, or in some cases misuse, of a public resource must be turned back to them for input at some point. Mr. Streatch, let's hear from you on that.

Panelist: Hon. Kenneth Streatch. I don't think there's any question about it. In my opinion, politicians are really 
politicians to serve people and l've never been one to believe that we, at the political level, have the answers to all questions. Indeed, sometimes, a very few answers. so, if we're going to bring forward the type of programs and policies and decisions that are appropriate then I think it's essential that we consult with those people we're serving. In Nova Scotia, $75 \%$ of our land is privately owned and that's a major component. If we're doing planning and this type of thing with somebody else's land, we need their input. We're convinced that we're on the right track. We certainly have the support of industry and I feel that, with that type of commitment from industry and land owners and governments, we'll be able to succeed in the process.

Panel Moderator: Pamela Wallin. Alright, back to you Mr. Merrithew. Several questions here ask if, in fact, the commitment to the forestry industry is as strong as everyone has repeatedly said over the last few days starting with the Prime Minister, then why has not the federal government appointed a full ministry of forests in clarification of that role?

Panelist: Hon. Gerald Merrithew. That is a legitimate question and I should have expected it. There are many people I know that felt that the Prime Minsiter might have chosen this particular opportunity to make that kind of an announcement. When we formed the new government, there hadn't been a full Minister of Forestry around the Cabinet table for a long time and the first was 1960, which a Conservative government announced then. I think it's far more important that there is someone in Cabinet speaking on behalf of forestry in Canada and working with his colleagues, the forestry ministers, to jointly and collectively try to do the things we know we have to do and to deal with the problems we know exist out there. The Prime Minister made the only decision he could have at that time within the Forestry Act, and he appointed a Minister of State to assist. A Minister of State can be attached to any department and he chose agriculture, as it is in the United States and most other countries around the world. Forestry being the largest industry in Canada, there were a lot of people who would have expected a full ministry and still do, including myself. I think you should look at results and the commitment of a government and the leadership that the government is showing in the sector and the amount of dollars and who's speaking for you. You could have a full ministry and a weak minister, or you might have quite the opposite. I think the important thing is as long as you have somebody fighting for you, trying to get the dollars you need, the programs you need, that's just as important. The Prime Minister will make the announcement at the appropriate time. probably.

Panel Moderator: Pamela Wallin. We almost got him to say something there. I'm going to throw a quote back to you, Mr. Merrithew, that was attributed to you several weeks ago. You said that federal laws governing forestry are primitive. If that is, in fact, the case, can you do anything about that, given your status, the less-than-full-minister status?

Panelist: Hon. Gerald Merrithew. The act that we're operating on is a 1966 act. Like all legislation, it is not carved in stone, it has to be amended from time to time to reflect that we're really doing. The act we now have doesn't reflect what we're doing in terms of agreements with my colleagues here, for example. We're doing an awful lot more than what the act says, really, so there is room for amendment and that can be done, and will be done in due course.

Panel Moderator: Pamela Wallin. There's a question here that I think is worth giving to every single minister and representative at the table. The person putting forward this question wants to know how each of you proposes to deal with your respective cabinets in the wake of this two-day meeting to ensure that the forest sector program funding is maintained as a basic minimum or enhanced, in the face of budget deficits and concerns that everybody in this country has. So let's start at the other end of the table with Mr. Simms and work our way along.

Panelist: Hon. Len Simms. First of all, of course, in the Cabinet system one can't disclose what he's going to say in Cabinet so that puts us in a difficult position right at the beginning

Panel Moderator: Pamela Wallin. We'll take a paraphrase.

Panelist: Hon. Len Simms. You'll take a paraphrase? Well, then I intend to fight very hard to ensure that funding for forestry will remain a high priority with the government of Newfoundland and Labrador, as it does now. That has happened over recent year, will continue, and I know that I'll get a considerble amount of support for that type of approach. That's the only answer one can really give, Pamela, other than telling you exactly what l'm going to say at the Cabinet table.

Panel Moderator: Pamela Wallin. As a result of the last two days in the Ministers' meetings you had and your exposure to all the different points of view that you've heard, can you suggest that you are, in fact, of the belief that more money should be put into this program?

Panelist: Hon. Len Simms. Of course we need more money for this program and that's what we're going to fight for. We're about to sign a new federal/provincial agreement. It will be an increase in funding over what we had the last five years. I'm proud of the agreement. We haven't announced the details of it, but sure we're going to continue to fight for more money, as any television network or radio station or whatever would do.

Panel Moderator: Pamela Wallin. Is it getting harder these days to keep this as a financial priority?

Panelist: Hon. Len Simms. Naturally. It's very difficult. There's one of the recommendations from this particular Congress that says "It was recommended to establish a framework for determining social and economic priorities and, therefore, appropriate levels of expenditures in forest management." I would submit that if there is anybody here who is going to be able to come up with that kind of framework, they would make a fortune for themselves because it is very, very difficult. It goes on all the time, but we will fight and we will get our share; I can only speak for our own province, we do get a substantial share right now.

Panel Moderator: Pamela Wallin. Mr. Streatch, is it getting difficult these days to free up dollars?

Panelist: Hon. Kenneth Streatch. Yes Pamela. I think there's no question about it that we, in the position of decision-making at government levels, are finding it more difficult everyday to be able to find enough dollars to service the people and yet provide new initiatives. All I can say, as far as the government of Nova Scotia is concerned, I've sat in the Cabinet room for the past eight years, on John Buchanan's government, and I've never taken on a task, a challenge, any more interesting than the one l've taken on the last two and a half years in forestry. I think it's very satisfying in the sense that I accepted 
that commitment and we've worked towards a provincial policy that is credible and, indeed, has some prospects for future development and employment opportunities. In this past number of months, at the federal and provincial level, through this forum, to come in with that same kind of commitment in Nova Scotia gives me quite a bit of satisfaction to be able to go back to the Cabinet table next week and say, look, we're not alone in this, other provinces across Canada are seeking the same type of commitment for new dollars and new commitment for forestry. I can simply say that I'm reasonably confident, in our part of the country, that the people are looking forward to continued expansion in that industry

Panel Moderator: Pamela Wallin. You've used a system of tax incentives in your province, which is slightly different than some of the others used. Is that a cheaper yet more effective way to approach some of the problems of forest management and maintaining the system?

Panelist: Hon. Kenneth Streatch. I think you always have to face the fact of how you can really assess value for dollars spent in a giveaway program. I'm rather of the opinion, and think it's come out at this conference, that incentives are the type of thing that stimulate one to, perhaps, think of new ways of doing things and really reward the type of progams that are beneficial. I have to say that the types of program that are going to be most beneficial, as far as taxpayer dollars are concerned, are those investing in the future.

Panel Moderator: Pamela Wallin. Alright. Mr. MacLeod, would you comment on the question of money around your Cabinet table, the priority that is given to this particular issue, to your particular ministry.

Panelist: Hon. Malcolm MacLeod. We've been fortunate because we've gone through this planning project and now have data that's available to us that we can work with. We realize that here we have the number one economic generator that produces, in that small province, about $\$ 1.3$ billion, and it far outweighs fisheries and agriculture combined. We know how important it is and we've been able to find money for things like the joint program with Nova Scotia and the Island for the Maritime Forest Centre in Fredericton that will cost us some $\$ 70$ million, cost-shared by the four governments. We've found money for spraying, we've found money for many facets of the silviculture program and we've done this without any misgivings. We know that we must do something to protect those jobs into the future and that's what it's all about. I think that's the sort of thing, when you boil it all down, that I think we must realize. We've come a long way from the last 100 years when we found trees to be a nuisance as we tried to get to the coast and we burned them, we did everything with them we could think of doing because they had very little value, or in New Brunswick shipped mast wood out of the Miramichi. We've come a long way, we've got a lot of pulpmills in our province, we've got a lot of sawmills, and we've got a lot of jobs and the Cabinet knows that. No, I'm not having any trouble getting money, I'm getting as much as I want and we are on austerity. The government is well aware that we can't do without the forests.

Panelist: Hon. Albert Côté. Yes, Pamela, everyone knows the importance that Mr. Bourassa gives to the economy. For my part, the budgets for this year are already prepared and there is not much room to manoeuver. What happens after the Congress and the two days we have spent here will not be so different for the coming year. All the same, I hope to draw attention to the public awareness campaign that has been launched today by the Canadian Council of Forest Ministers which I hope will help me obtain supplementary funds. We are putting a great deal of emphasis on forest management and the new forest policy which we shall soon introduce in Quebec. Already commitments have been made on this major forest management program. This year we have through tax and credit measures encouraged private woodlot owners to carry out better management on their properties. We are putting much effort and money into these initiatives and I am confident that each dollar spent will be a profitable investment for future generations.

Panel Moderator: Pamela Wallin. We'll go now to British Columbia. Mr. Heinrich, I want you to stay on the same focus about the kind of priority that you think, for the province where the industry is so important: and there are several questions directed at you as I go through this list about the use of money and how your government approaches it and, in fact, saying money might be better spent directly on planting more trees.

Panelist: Hon. Jack Heinrich. First of all, the budget in British Columbia for the Ministry of Forests introduced last month, gave us a $21 \%$ lift, which is very, very substantial. It was the largest lift among all the ministries. Yes, there's well in excess of $\$ 6$ billion worth of products coming out of the province. Funding, as a result of the federal/provincial agreement, for the backlog has increased substantially. We've increased what we refer to as the Section 88 allowance, I think from roughly $\$ 62$ million to $\$ 90$ million, which is a credit given to companies for doing particular types of work. We've increased the small business enterprise program for access and reforestation. Our objective is 200 million seedlings annually and, to put it in perspective, that's a billion seedlings over the next five years, ' 87, ' 88 and following; and it seems to me, from the reading that I've done recently, a billion seedlings went into the province during its previous history so we've made considerable progress.

The most important thing that l'd like to mention here is that seedlings are not enough. It's a matter of intensive silviculture practice and the effort must go into that area. Hence, the introduction of a bill, which I mentioned a moment ago. We're looking for participation. The question was raised by you, on how do you get industry, the public sector, forest unions, municipalities, others who are interested, all involved? One of the biggest concerns that I think all people in industry and all ministers of forests have had is the insatiable demands which have come from the social ministries. Just coming out of the education portfolio, I recognize what the demands are and how difficult it is to hold the line; but what I'm really looking for, and our government is, is establishment of a fund that is going to be inviolate and something which all will participate in. I'm looking to industry, I'm looking to the public sector trade unions, l'm looking to other levels of government as well as anyone who is interested, municipalities for example, to participate so that that fund is there for intensive silviculture practices. This is something that's going to grow: I've given a commitment to it; government has given a commitment to it as well.

Panelist: Mr. Frank Appleby. The Minister from Newfoundland said, in prefacing his remarks, he wasn't about to divulge what would be said in Cabinet; in a sense, I'm one more step down the line, I'm free from that responsibility. I just wanted to make one little comment about the discussion we had earlier about a full ministry for the federal government because we felt that what we have gained so far in having a Minister of State for Forestry is a big plus because we've been looking for that and agitating for that for a number of years. I compare that 
with our position in Alberta where we now have a Minister of Forestry and we've been doing the same thing there for a number of years to achieve that objective, so we're pleased. We, in Alberta, have been in the very fortunate position in that we have had excellent revenues from non-renewable resources and have been able to achieve certain things in forestry that, perhaps, we wouldn't have been able to do had we not had those kind of resources - things like developing a massive nursery and very sophisticated fire suppression programs. We're in a state now where we don't know what the future will hold for those revenues, but we do feel that we will not be in any way restricted in the matter of funding, as we've had it up to the present time. In fact, what we're looking at today is the fact that we have a number of plants in our province that have reached a stage of obsolescence and we feel that something has to be done to assist them so that they can achieve better productivity. We don't anticipate anything less.

Panel Moderator: Pamela Wallin. Mr. Maxwell, with higher provincial deficits what do you do? Can you still spend money on this, new money?

Panelist: Hon. Colin Maxwell. Well, the new money that's being committed is obviously going to be used in the manner in which it was intended. Otherwise we could not possibly accept it in good grace and still look Gerry Merrithew in the eye. When I get back to Saskatchewan, there is going to be a white paper for consultation floated as a precursor to a new Forest Act which, after the election and Grant Devine and the government are returned, we intend to introduce in the fall sitting of the legislature. What we have in Saskatchewan is positively an antedeluvian set of regulations and policies governing forestry and we have to clean it up. We are playing catch-up for years of mismanagement, lack of reforestation and positively poor attitudes towards silviculture in a province where we do have a very viable forest industry, if it were to be managed correctly. I tell you those days are over and we're not going back to them.

Panel Moderator: Pamela Wallin. Mr. Kerrio, we'll give you the final provincial word here on how you intend to maintain this as a priority when there are so many competing interests for any provincial government.

Panelist: Hon. Vincent Kerrio. I would like to relate to a former question and say I wouldn't trade our ambassador, Gerry Merrithew, for a full-blown ministry unless he is the Minister because this forum, I think, has a good feeling. Relating to my particular responsibility in Ontario, we have an extremely high value-added to our timber products and so a commitment was made. I'm the recipient of some very good planning that went on before. Some five years ago we entered into a forest management agreement that put considerably more responsibility on the people that harvest the trees and we as a government are now free to do more prime site work, more research and so on. We put a substantial amount of money, some \$64 million, into the forest management agreements. That does not cover the cost of building roads, of planting and doing all those things. The industry picks up the balance so there is a good arrangement. We planted some 125 million trees last year, but planting is not quite good enough. We now have an agreement from thsoe companies that they will reach the free-to-grow stage and that's the only time you can count a tree is when it's free to grow. So, it's been an excellent opportunity for me as minister to carry on with that program that was initiated. We have some $\$ 200$ million committed to the forest management program in Ontario, 70 -
$80 \%$ of that directed to regeneration. We've had the first audits, also, of the five-year plan, this year. They're excellent; the regeneration has been good, I'm very pleased at the audit. We've done one more thing in Ontario that's very important. There's a lot of examination by many people about the state of the forest. We have, for the first time, taken an independent person, Dr. Baskerville, to do an audit of the forests of Ontario and the methods we use. I feel very comfortable with what we're doing and the government has made a commitment of money.

Panel Moderator: Pamela Wallin. I want to put that question, I'm glad you raised it, to Mr. Merrithew. Will the ministry use this Congress as a perfect opportunity to announce the launching of an independent forest inventory audit board, which would report to the people of Canada on the status of our forests every five or ten years, or on a regular basis?

Panelist: Hon. Gerald Merrithew. No. I liked your former question, l'd like to comment on that first. No, we haven't had that put forward very forcefully. Obviously, if we were to do that, it would have to be thought out very carefully. No, we have no plans at present for an independent forest inventory board.

Panel Moderator: Pamela Wallin. Do you see that as a federal priority? Is that, perhaps, one of the roles of the federal government to do an assessment of where everything stands in this country from coast to coast?

Panelist: Hon. Gerald Merrithew. We've got a unique federal system. Many people would ask why should we even have a minister of state for forestry. We don't own the forests of Canada, these fellows do. The people of Canada own $90 \%$ of the forests in the right of the provinces; we own a few parks, a few Indian reservations and a few national defence bases, but that's it. There's always the question as what are we doing, what role, what responsibilities really do we have in terms of commitment. You'd have to have, obviously, the co-operation of the provinces on anything like that because the jurisdictional responsibilities of the forests of Canada belong to the provinces. There might be a moral responsibility for the federal government because we get revenues from the forest land, but I haven't taken that much time to really think, definitively, what we do with that.

Panel Moderator: Pamela Wallin. Alright, you wanted to comment on the financial question in general.

Panelist: Hon. Gerald Merrithew. I just wanted to mention one thing. Ladies and gentlemen, governments respond to what the people say is important. If the people of Canada say the forest of Canada are important, there will be money going to them, simple as that. One of the jobs you people have is to raise the profile. It isn't up to us, but no matter if we raise the profile of this sector and say to the people of Canada it is important to you, it is important to trade, it's important to jobs, it's important to investment, for every person who works in a pulp and paper company - everyone of them - \$350,000 has been invested in it.

Panel Moderator: Pamela Wallin. You've got a Gallup poll, I know, that you were reading quite recently, Mr. Merrithew, what did it tell you?

Panelist: Hon. Gerald Merrithew. Yes, remember I mentioned the public awareness program which we announced this afternoon. Gallup did a poll for us and it was interesting that the people of Canada realize forestry is 
important, they said the second most important industry after agriculture. Now, they know it's relatively important on a scale of $10,7.7$ and agriculture is 8.1. Incidentally, forestry is way larger than agriculture. When we went down and continued the poll there were all sorts of very, very interesting things. It showed that they have an awareness and I think they recognize the importance of it, relatively; but there were a lot of misconceptions after that and that's what we're going to try to correct in our public awareness program.

Panel Moderator: Pamela Wallin. I guess we're running quickly out of time here. Is there anybody else that would care to respond to that, any of the Ministers at the table, on the public awareness question, whether or not you respond to political heat, is that what makes you move?

Panelist: Hon. Malcolm MacLeod. We have a wildlife advisory group that's being assembled and we are dialoguing with those people more - outfitters, naturalists and so on. I heard some concern today, during the speeches, that those people had something to say which they thought was not being heard; I think in raising the profile of the forest it is important to bring these people in - the environmentalists, naturalists and others. We must, number one, get rid of some of the misinformation; and number two, convince the upcoming generation that it is their forests on Crown land, not the Crown's forests. We want them to get a general love and appreciation that the forest is theirs. I think we've really got to work at that.

Panelist: Hon. Jack Heinrich. I think the comments of the Minister from New Brunswick were bang on, but I tell you one thing that l've learned in a very short period of time - coming from a province which is, you know, heavily into the forest industry and from a riding where I have a half a dozen pulpmills and 12 major sawmills, for starters - that really people have taken the forest for granted. This morning one panelist made reference to the word perception. Frankly, it's a word I don't particularly like, it becomes a cliché that's been overused, but what's the public saying? When I walked into the forum a couple of days ago, somebody from British Columbia planted this carrot on me and I thought to myself, it's a very soft twoby-four to get our attention. I thought to myself, we haven't done our job, as politicians, to get it across as well as we should, but I don't think industry has been all that great either. From our province's point of view, I think the point has been well made that with the increased funding and activities which are now going on, but people have taken the forests for granted. I wonder what would have happened if our area, our land mass, was much smaller and what would people have been thinking. We saw a picture this morning of part of Japan, what did that tell us? They're aware.

Panelist: Hon. Albert Côté. I would add that we already have an important publicity and communications program in Quebec and in light of the national awareness program that is being initiated, I shall approach our provincial treasurer to obtain new money to add to the information program we already have. I would add that our appreciation of the importance of the forest to Quebec can best be seen in our budget which has an increase of $6.7 \%$ over the last year over the rate of inflation. With a Congress like this and a wellorganized publicity campaign, I am sure that the public will get to better understand and respect our forests and to support their management.

Panel Moderator: Pamela Wallin. We're running out of time so l'll just make a couple of very brief comments. It seems today that, despite all the questions, we were pretty short on specifics; but by the admissions of each of the Ministers, there is, in fact, a way to help resolve that and that is to bully them. They seem to respond to public opinion and public pressure, so do that. All of you who put your questions forward who did not get them answered - we couldn't possibly have got through them all - I invite you, on behalf of all of the Ministers, to write to them at their offices and put those specific questions forward. We are going to turn to Mr. Merrithew for a wrap-up statement from this panel. 